\title{
Thyroid and other autoantibodies in British and Japanese women: an epidemiological study of breast cancer
}

\author{
I MITTRA, J PERRIN, S KUMAOKA
}

British Medical fournal, 1976, 1, 257-259

\section{Summary}

To define the role of asymptomatic autoimmune thyroiditis in the cause of breast cancer, the presence of circulating thyroid autoantibodies was studied in two populations, one with a high risk of breast cancer (British women) and one with a low risk (Japanese women). Ostensibly healthy women and patients with breast cancer from both countries were studied. There was no difference in the incidence of thyroid autoantibodies between women with breast cancer and healthy women in either race. The incidence of thyroid autoantibodies in healthy British women, however, was two to three times that in healthy Japanese women. The incidence of reticulin antibodies, was considerably higher in both groups of Japanese women. No remarkable differences in the incidence of antinuclear, smooth-muscle, antimitochondrial, gastric parietal cell, or liver-kidney microsomal antibodies were found between women with breast cancer and healthy women or between the two races. Only the incidence of antinuclear antibodies was marginally higher in Japanese patients with advanced cancer.

These results indicate that asymptomatic autoimmune thyroid disease is more prevalent among British than among Japanese women, but they fail to provide direct evidence that autoimmune thyroid disease is associated with breast cancer. Prospective studies of women with autoimmune thyroiditis and studies of young women from low-risk and high-risk populations are needed.

\section{Introduction}

The incidence of breast cancer is substantially lower in Japan than in the West, a difference that cannot be explained entirely by the known risk factors in breast cancer. ${ }^{1}$ It has recently been suggested that subclinical hypothyroidism may be an important factor in the aetiology of this disease ${ }^{2}$ and that geographical variations in the incidence of breast cancer may be related to racial differences in thyroid status. ${ }^{2-4}$ Mittra et $^{-1} l^{5}$ have suggested, on the basis of experimental evidence, ${ }^{6}{ }^{7}$ that a suboptimal level of circulating thyroid hormones may abnormally sensitise mammary epithelial cells to prolactin stimulation, which may lead to dysplasia and eventual neoplasia. It has recently been established that some of the healthy population have circulating thyroid autoantibodies indicative of asymptomatic lymphocytic thyroiditis. ${ }^{8}{ }^{9}$ Furthermore, the presence of these autoantibodies

Guy's Hospital, London SE1 9RT

I MITTRA, FRCS, senior registrar, department of surgery

The London Hospital, London E1 4DG

J PERRIN, MD, MRCP, consultant, department of clinical immunology

National Cancer Centre Hospital, Tsukiji 5-Chome, Chuo-Ku, Tokyo, Japan

S KUMAOKO, MD, chief of department of medicine in some of these ostensibly healthy people is related to subclinical thyroid failure, as evidenced by raised serum thyrotrophin levels ${ }^{1-13}$ or abnormalities of cholesterol metabolism. ${ }^{14}$ We therefore studied the incidence of autoimmune thyroid disease in two populations, one with a high and the other with a low incidence of breast cancer. The incidence of circulating thyroid autoantibodies was assessed in healthy women and those with breast cancer from Britain and Japan.

Recent studies have suggested that the incidence of certain non-organ-specific autoantibodies is increased in breast cancer ${ }^{15-17}$ and that the number of these antibodies present in one individual is related to the risk of recurrence after mastectomy. ${ }^{17}$ Therefore we studied the incidence of antinuclear (ANA), smooth muscle (SMA), and antimitochondrial antibodies (AMA) in the two populations. We also assessed the incidence of reticulin antibodies (RA) and liver-kidney microsomal (LKM) and gastric parietal cell (GPC) antibodies.

\section{Subjects and methods}

Healthy women-A total of 211 British and 96 Japanese, ostensibly healthy, female volunteers were randomly selected for study. None of the Japanese were in hospital, but 44 of the British women were in hospital awaiting surgery for minor conditions unrelated to the immune or endocrine systems. Since the incidence of the various circulating autoantibodies in this subgroup was similar to that in the women who were not in hospital we considered that their inclusion in the healthy group was justified. No one with a history of thyroid disease was accepted for study.

Patients with breast cancer-These were 277 British and 85 Japanese women with early or advanced breast cancer who had been admitted to the breast cancer unit at Guy's Hospital, London, or The National Cancer Centre Hospital, Tokyo. Blood was collected from patients with early breast cancer (defined as T1 or 2 , NO or 1 , and MO in the TNM tumour classification system ${ }^{18}$ ) during the 48 hours before mastectomy. Patients with advanced breast cancer were those with locally advanced disease or distant metastases. Most of these patients had had, singly or in combination, oophorectomy, androgen or oestrogen treatment, and deep $x$-ray treatment. None of the patients had had hypophysectomy, adrenalectomy, or cytotoxic drugs. Blood was collected during their admission to hospital for consideration for endocrine ablation or deep $x$-ray treatment. Those with a history of thyroid disease were not accepted.

Age-There was no statistical difference between the age distribution in the various groups (fig 1). The age distribution of the two subgroups of patients with breast cancer (early and advanced) was also comparable with that of the healthy women of the same nationality. Most women $(80-90 \%)$ were aged 40 to 70 years.

Collection of blood-Blood was collected from all subjects in standard heparinised Vacutainers. Plasma was separated at $4^{\circ} \mathrm{C}$ and stored at $-20^{\circ} \mathrm{C}$. The Japanese samples were flown to London in a frozen state.

Immunofluorescence and serological tests were done without prior knowledge of the source of the plasma samples.

Immunofluorescence - Thyroid cytoplasmic (microsomal) antibodies, ANA, SMA, AMA, RA, LKM antibodies, and GPC antibodies were detected by indirect immunofluorescence. Cryostat sections $5-\mu \mathrm{m}$ thick were cut from a composite block of tissues including human toxic thyroid and stomach and rat stomach, liver, and kidney. Plasma samples were tested at a dilution of $1 / 5$. A polyvalent antihuman $\delta$-globulin FITC conjugate was then applied and the sections were examined with a Zeiss microscope using epi-illumination with a CSI lamp.

Serological tests-Thyroid microsomal antibody titre was estimated by haemagglutination and complement fixation tests. The former was 


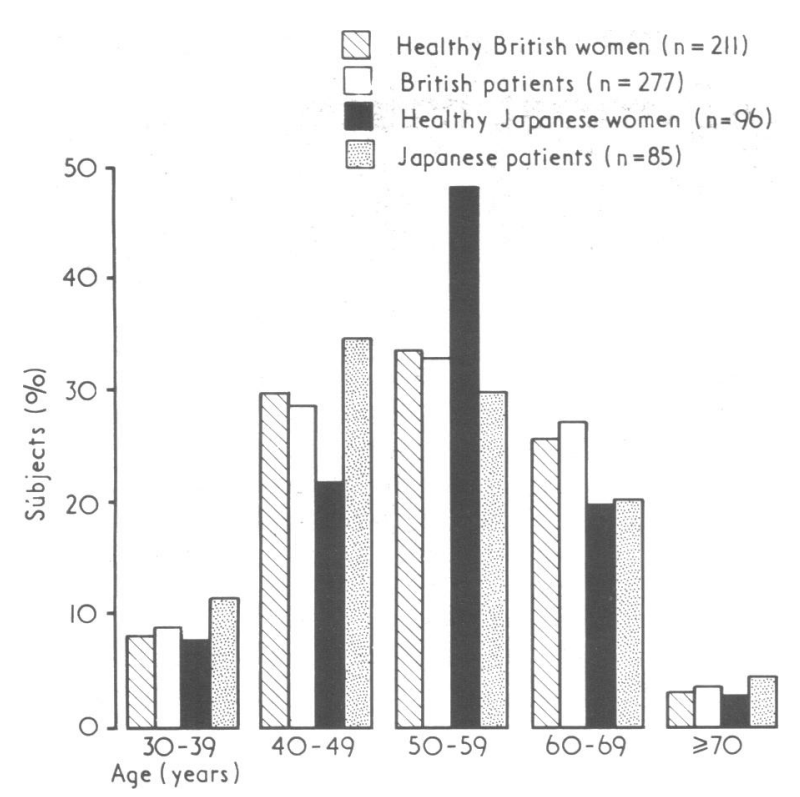

FIG 1-Age distribution of subejcts studied.

done by the method of Perrin and Bubel ${ }^{19}$ starting at an initial dilution of $1 / 10^{2}$ (reagents supplied by Fujizoki Pharmaceutical Co). The complement fixation antigen was a saline extract of toxic thyroid gland. Thyroglobulin antibody was measured by a haemagglutination test ${ }^{20}$ using tanned red cells supplied by Burroughs Welcome; a titre of $1 / 20$ or above was considered positive.

Statistical analysis-The data was analysed by $\chi^{2}$ test.

\section{Results}

The incidence and the titres of circulating thyroid autoantibodies did not differ materially between the patients with cancer and healthy women in either- race. On comparing the incidence among healthy women, however, important differences emerged between the two races (fig 2). Thyroid microsomal antibodies, as detected by immunofluorescence, were three times as common in the British as in the Japanese women. Similarly, the incidence of these antibodies when measured by the haemagglutination test was between three and four times higher in the British women. The incidence of microsomal antibodies measured by the complement fixation test and the incidence of thyroglobulin antibodies measured by haemagglutination, although again substantially higher in British women, were not significantly higher than in Japanese women because of the few positive cases and the relatively small size of the Japanese population. The overall incidence of thyroid autoantibodies (microsomal \pm thyroglobulin) was significantly higher in the British women than in the Japanese. A second major difference between the two races, irrespective of the occurrence of breast cancer, was the high incidence of RA in the Japanese (table I).

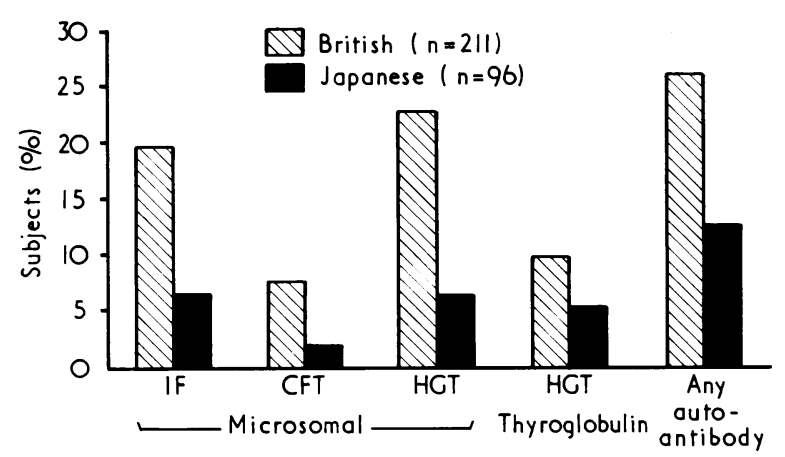

FIG 2-Incidence of thyroid autoantibodies in healthly British and Japanese women. IF $=$ Immunofluorescence. $\mathrm{CFT}=$ Complement fixation test. HGT = Halmagglutination test.

TABLE II-Percentage incidence of multiple autoantibodies ( $A N A, S M A$, and $A M A)$ in British and fapanese women

\begin{tabular}{|c|c|c|c|c|}
\hline & $\begin{array}{c}\text { No of } \\
\text { subjects }\end{array}$ & $\begin{array}{c}\text { No } \\
\text { autoantibody }\end{array}$ & $\stackrel{1}{\text { Autoantibody }}$ & $\underset{\text { Autoantibody }}{>1}$ \\
\hline \multicolumn{5}{|c|}{ British } \\
\hline $\begin{array}{l}\text { Healthy women } \\
\text { Women with breast }\end{array}$ & 211 & $71 \cdot 1$ & $26 \cdot 5$ & $2 \cdot 3$ \\
\hline cancer: & & & $24 \cdot 8$ & 6.0 \\
\hline $\begin{array}{l}\text { Early } \\
\text { Advanced }\end{array}$ & $\begin{array}{l}149 \\
128\end{array}$ & $\begin{array}{l}69 \cdot 1 \\
64 \cdot 8\end{array}$ & $\begin{array}{l}24 \cdot 8 \\
28 \cdot 1\end{array}$ & $\begin{array}{l}0.0 \\
7 \cdot 0\end{array}$ \\
\hline Total & 277 & $67 \cdot 1$ & $26 \cdot 4$ & $6 \cdot 5$ \\
\hline \multicolumn{5}{|c|}{ fapanese } \\
\hline Healthy women & 96 & $71 \cdot 8$ & $22 \cdot 9$ & $5 \cdot 2$ \\
\hline $\begin{array}{l}\text { Women with breast } \\
\text { cancer: }\end{array}$ & & & & \\
\hline Early & 29 & $65 \cdot 5$ & 34.5 & 0 \\
\hline Advanced & $\begin{array}{l}56 \\
85\end{array}$ & $\begin{array}{l}53.5 \\
57.6\end{array}$ & $\begin{array}{l}33 \cdot 9 \\
34.1\end{array}$ & $\begin{array}{r}12 \cdot 5 \\
8 \cdot 2\end{array}$ \\
\hline Total & 85 & $57 \cdot 6$ & $34 \cdot 1$ & $8 \cdot 2$ \\
\hline
\end{tabular}

There was no racial difference in the incidence, or in the titres, of the three non-organ-specific antibodies-ANA, SMA, and AMA. The incidence of ANA and SMA was slightly increased in patients with cancer, although this difference was statistically significant only for ANA in Japanese patients with advanced breast cancer $(P<0.05)$. The incidence of AMA in women with cancer was similar to that in healthy women.

Table II shows the incidence of multiple autoantibodies (combinations of ANA, SMA, and AMA). Patients with breast cancer showed no greater tendency to have multiple autoantibodies than healthy women.

TABLE I-Percentage incidence of various autoantibodies in British and fapanese women

\begin{tabular}{|c|c|c|c|c|c|c|c|c|c|c|c|c|}
\hline & \multirow{3}{*}{$\begin{array}{c}\text { No of } \\
\text { subjects }\end{array}$} & \multicolumn{5}{|c|}{ Thyroid autoantibodies } & \multirow{3}{*}{$\begin{array}{c}\text { GPC } \\
\text { antibodies }\end{array}$} & \multirow{3}{*}{ ANA } & \multirow{3}{*}{ SMA } & \multirow{3}{*}{ AMA } & \multirow{3}{*}{ RA } & \multirow{3}{*}{$\begin{array}{c}\text { LKM } \\
\text { antibodies }\end{array}$} \\
\hline & & \multicolumn{3}{|c|}{ Microsomal } & \multirow{2}{*}{$\frac{\text { Thyroglobulin }}{\begin{array}{c}\text { Haem- } \\
\text { agglutination }\end{array}}$} & \multirow{2}{*}{ Any } & & & & & & \\
\hline & & $\begin{array}{c}\text { Immuno- } \\
\text { fluorescence }\end{array}$ & $\begin{array}{c}\text { Complement } \\
\text { fixation }\end{array}$ & $\begin{array}{c}\text { Haem- } \\
\text { agglutination }\end{array}$ & & & & & & & & \\
\hline \multicolumn{13}{|c|}{ British } \\
\hline $\begin{array}{l}\text { Healthy women } \\
\text { Women with } \\
\text { breast cancer. }\end{array}$ & 211 & $19 \cdot 9 *$ & $7 \cdot 6$ & $22 \cdot 7 \dagger$ & $9 \cdot 9$ & $26 \cdot 0 \ddagger$ & $3 \cdot 8$ & $19 \cdot 4$ & $12 \cdot 3$ & $1 \cdot 4$ & $2 \cdot 8$ & 0 \\
\hline $\begin{array}{l}\text { Early } \\
\text { Advanced } \\
\text { Total }\end{array}$ & $\begin{array}{l}149 \\
128 \\
277\end{array}$ & $\begin{array}{l}19 \cdot 5 \\
16 \cdot 4 \\
18 \cdot 0\end{array}$ & $\begin{array}{l}6 \cdot 7 \\
2 \cdot 3 \\
4 \cdot 6\end{array}$ & $\begin{array}{l}22 \cdot 2 \\
17 \cdot 2 \\
19 \cdot 9\end{array}$ & $\begin{array}{l}14 \cdot 7 \\
17 \cdot 9 \\
16 \cdot 2\end{array}$ & \begin{tabular}{|l|}
31.5 \\
27.3 \\
29.6
\end{tabular} & $\begin{array}{l}4 \cdot 0 \\
4 \cdot 7 \\
4 \cdot 3\end{array}$ & $\begin{array}{l}20 \cdot 8 \\
25 \cdot 0 \\
22 \cdot 7\end{array}$ & $\begin{array}{l}18 \cdot 8 \\
17 \cdot 9 \\
18 \cdot 4\end{array}$ & $\begin{array}{l}1 \cdot 3 \\
1.5 \\
1 \cdot 4\end{array}$ & $\begin{array}{l}1 \cdot 3 \\
3 \cdot 1 \\
2 \cdot 2\end{array}$ & $\begin{array}{l}0 \\
0 \\
0\end{array}$ \\
\hline \multicolumn{13}{|c|}{ Fapanese } \\
\hline $\begin{array}{l}\text { Healthy women } \\
\text { Women with } \\
\text { breast cancer: } \\
\text { Early } \\
\text { Advanced } \\
\text { Total }\end{array}$ & $\begin{array}{l}29 \\
56 \\
85\end{array}$ & $\begin{array}{l}6 \cdot 8 \\
3 \cdot 5 \\
4 \cdot 7\end{array}$ & $\begin{array}{l}0 \\
1 \cdot 7 \\
1 \cdot 1\end{array}$ & $\begin{array}{l}6 \cdot 8 \\
3 \cdot 5 \\
4 \cdot 7\end{array}$ & $\begin{array}{r}10 \cdot 3 \\
8 \cdot 9 \\
9 \cdot 4\end{array}$ & $\begin{array}{l}13 \cdot 7 \\
10 \cdot 7 \\
11 \cdot 7\end{array}$ & $\begin{array}{l}6 \cdot 8 \\
5 \cdot 3 \\
5 \cdot 8\end{array}$ & $\begin{array}{l}15 \cdot 3 \\
30 \cdot 3 \\
24 \cdot 7\end{array}$ & $\begin{array}{l}20 \cdot 6 \\
21 \cdot 4 \\
21 \cdot 1\end{array}$ & $\begin{array}{l}0 \\
3 \cdot 5 \\
2 \cdot 3\end{array}$ & $\begin{array}{r}6 \cdot 8 \\
14 \cdot 2 \\
11 \cdot 7\end{array}$ & $\begin{array}{r}0 \\
1 \cdot 7 \\
1 \cdot 1\end{array}$ \\
\hline
\end{tabular}

Values significantly different from those of healthy Japanese women:

* $\mathrm{P}<0.01$. $+\mathrm{P}<0.005$. $\$ \mathrm{P}<0.05$. $\| \mathrm{P}<0.001$.

\$Values was significantly different from that for Japanese patients with advanced breast cancer $(P<0.05)$. 
The apparent difference in the incidence of multiple autoantibodies between Japanese women with early breast cancer and Japanese women with advanced cancer could not be statistically evaluated because of the small numbers studied, and may require further examination in a larger series.

The incidence of the organ-specific antibodies (LKM and GPC antibodies) was not significantly different in any group, although the incidence of GPC antibody was slightly higher among Japanese women with breast cancer.

\section{Discussion}

We observed a higher incidence of circulating thyroid autoantibodies in British women, a population with a high risk of breast cancer, than in the Japanese, a population with a low risk. This finding seems to indicate that asymptomatic autoimmune thyroid disease is more prevalent in British women than in Japanese women. On the other hand, the incidence of thyroid autoantibodies in patients with established breast cancer in either race was no higher than in their respective populations of healthy women. Our results, therefore, fail to provide any direct evidence that autoimmune thyroid disease is associated with breast cancer. Additional prospective studies, in which many women with lymphocytic thyroiditis should be followed up for a long period, will be required to establish the precise implications of this condition in the aetiology of breast cancer. It has been suggested that aetiological factors in breast cancer operate only in the early reproductive years of a woman's life $^{2122}$ and that these factors may not be apparent in case control studies several decades later when the tumour becomes clinically established. ${ }^{21}$ Studies in young women from high-risk and low-risk populations, might, therefore, help to define further the aetiological role of asymptomatic autoimmune thyroiditis in breast cancer.

The presence of thyroid autoantibodies in over a quarter of the adult British women studied agrees with our earlier observations, and those of others, ${ }^{23}$ on the incidence of autoantibodies in middle-aged women. Similarly, an incidence of thyroid antibodies of $9 \%$ in Japanese women, reported by Ohmi et al, ${ }^{24}$ agrees with the low incidence we observed. The underlying factors responsible for this racial difference in thyroid autoimmunity are unknown.

Among the other autoantibodies studies, the high incidence of RA in the Japanese was unexpected and requires further investigation. These antibodies included $R_{1}, R_{2}, R_{s}$, Kupffer cell, and adherent cell types, ${ }^{25}$ the commonest being the $\mathbf{R}_{s}$ pattern, sometimes combined with $R_{1}$.

The incidence of ANA and SMA showed no racial differences. Although patients with breast cancer had a slightly higher incidence of ANA and SMA only the incidence of ANA in the Japanese with advanced cancer was significantly higher than that in healthy Japanese women. Whitehouse and Holborow found these two antibodies in over half of their 12 patients with breast cancer ${ }^{15}$-a much higher incidence than we observed. Similarly, Wasserman et $a l^{17}$ reported an incidence of about $35 \%$ in patients with operable breast cancer, the incidence being further increased to $50 \%$ in those in whom the disease recurred. Our data on different antibodies-ANA, SMA, and AMAoccurring singly or together in the same patient (table II), do not support the contention of Wasserman et $a l^{17}$ that multiple autoantibodies are commoner in patients with breast cancer, especially those who develop recurrence of disease.

We thank Mr J L Hayward and Dr R D Bulbrook for their encouragement and support, Drs D Y Wang, I Adachi, and K Abe for their help in this study, and $\mathrm{Mr}$ A J Appleyard for his skilful technical help.

This study was supported in part by a grant for cancer research from the Ministry of Health and Welfare, Japan.

Requests for reprints should be addressed to Mr I Mittra, Department of Surgery, Guy's Hospital, London SE1 9RT.

ADDENDUM-Since this paper was prepared it has been reported that the risk of breast cancer is increased fivefold to sixfold in women with Hashimoto's thyroiditis. ${ }^{26}$

\section{References}

${ }^{1}$ Wynder, E L, Bross, I J, and Hirayama, T, Cancer, 1960, 13, 559.

${ }^{2}$ Mittra, I, and Hayward, J L, Lancet, 1974, 1, 885.

3 Bogardus, G M, and Finley, J W, Surgery, 1961, 49, 461

4 Eskin, B A, Transactions of the New York Academy of Sciences, 1970,32,911.

${ }^{5}$ Mittra, I, Hayward, J L, and McNeilly, A S, Lancet, 1974, 1, 889.

${ }^{6}$ Mittra, I, Nature, 1974, 248, 525.

${ }^{7}$ Mittra, I, Experientia, 1975, 31, 1218.

${ }^{8}$ Goudie, R B, Anderson, J R, and Gray, K G, Fournal of Pathology and Bacteriology, 1959, 77, 389.

9 Bastenie, P A, et al, Lancet, 1967, 1, 915.

10 Bonnyns, M, and Bastenie, P A, fournal of Clinical Endocrinology and Metabolism, 1967, 27, 849 .

11 Gordin, A, et al, Lancet, 1972, 1, 551.

12 Evered, D C, et al, British Medical fournal, 1973, 1, 657.

13 Tunbridge, W M G, and Evered, D, Excerpta Medica International Conference Series, 1975, 361, 175.

${ }^{14}$ Fowler, P B S, Swale, J, and Andrews, H, Lancet, 1970, 2, 488.

15 Whitehouse, J M A, and Holborow, E J, British Medical fournal, 1971, 4, 511 .

16 Whitehouse, J M A, British fournal of Cancer, 1973, 28, suppl 1, p 170.

17 Wasserman, J, Glas, U, and Blomgren, H, Clinical and Experimental Immunology, 1975, 19, 417.

18 TNM Classification of Malignant Tumours, Geneva, UICC, 1974.

19 Perrin, J, and Bubel, M A, Medical Laboratory Technology, 1974, 31, 205.

20 Fulthorpe, A J, et al, fournal of Clinical Pathology, 1961, 14, 654.

21 MacMahon, B, Cole, P, and Brown, J, Fournal of the National Cancer Institute, 1973, 50, 21.

22 Cairns, J, Nature, 1975, 255, 197.

${ }^{23}$ Doniach, D, and Roitt, I M, in Clinical Aspects of Immunology, ed P G H Gell, R R A Coombs, and P J Lachman, p 1355. Oxford and Edinburgh, Blackwell Scientific, 1975.

${ }^{24}$ Ohmi, T, et al, Progress in Medicine, 1974, 89, 168 (in Japanese).

${ }^{25}$ Rizzetto, M, and Doniach, D, Fournal of Clinical Pathology, 1973, 26, 841.

26 Itoh, K, and Maruhi, N, Lancet, 1975, 2, 1119. 